\section{Dødelighet}

\section{ved type 1-diabetes}

Pasienter med type 1-diabetes og god glykemisk kontroll har dobbelt så høy risiko for død sammenliknet med parede kontrollpersoner.

I Norge er det rundt 25000 personer med type 1-diabetes. I en stor, svensk registerstudie har man undersøkt hvordan overdødelighet hos pasienter med type 1-diabetes påvirkes av glykemisk kontroll (1).

Alle svenske pasienter med type 1-diabetes i perioden 1998-2011 ble fulgt i median åtte år. For hver pasient var det fem samsvarende kontrollpersoner fra den øvrige befolkningen, til sammen nesten 170000 personer. Total dødelighet $\mathrm{i}$ diabetesgruppen var $8,0 \%$, mot 2,9\% i kontrollgruppen. Henholdsvis $2,7 \%$ og $0,9 \%$ av dødsfallene hadde kardiovaskulære årsaker. Hos diabetikere med $\mathrm{HbA}_{1 \mathrm{c}} \leq 6,9 \%$ var hasardratio $2,36(95 \% \mathrm{KI}$ $1,97-2,83)$ for total dødelighet og 2,92 (95\% KI 2,07-4,13) for kardiovaskulær død, sammenliknet med kontrollpersonene. Dette gjaldt også for diabetikere med normoalbuminuri. Dødeligheten økte med dårligere glykemisk kontroll. Hos pasienter under 30 år var en tredel av dødsfallene relatert til diabetisk ketoacidose og koma.

- Det overraskende og viktigste funnet i denne studien er at også godt regulerte diabetespasienter og pasienter med normoalbuminuri har en betydelig overdødelighet, sier John G. Cooper, som er overlege i endokrinologi og medisinsk ansvarlig for Norsk diabetesregister for voksne.

- En svakhet ved studien er at det manglet komplette $\mathrm{HbA}_{1 \mathrm{c}}$-data for mange pasienter, dvs. at noen pasienter i gruppen med god glykemisk kontroll kan ha hatt dårligere kontroll tidligere. Dette kan kanskje forklare noe av overdødeligheten. Sannsynligvis har selv pasienter med god glykemisk kontroll vesentlig høyere glukoseverdier enn den øvrige befolkningen, og dette kan bidra til økt risiko for kardiovaskulær sykdom og død. Studien forsterker argumentene for intensivert blodsukkersenkende behandling og reduksjon av annen kardiovaskulær risiko hos alle pasienter med type 1-diabetes. Den understreker også hvor viktig det er å redusere akutte komplikasjoner, spesielt hos dem som er yngre enn 30 år, sier Cooper.

\section{Lise Mørkved Helsingen}

Tidsskriftet

\section{Litteratur}

1. Lind M, Svensson AM, Kosiborod M et al. Glycemic control and excess mortality in type 1 diabetes. N Engl J Med 2014; 371: 1972-82.

\title{
Stor variasjon i kreftoverlevelse
}

\section{Overlevelsen fem år etter å ha fått en kreftdiagnose varierer mye mellom} land og verdensdeler.

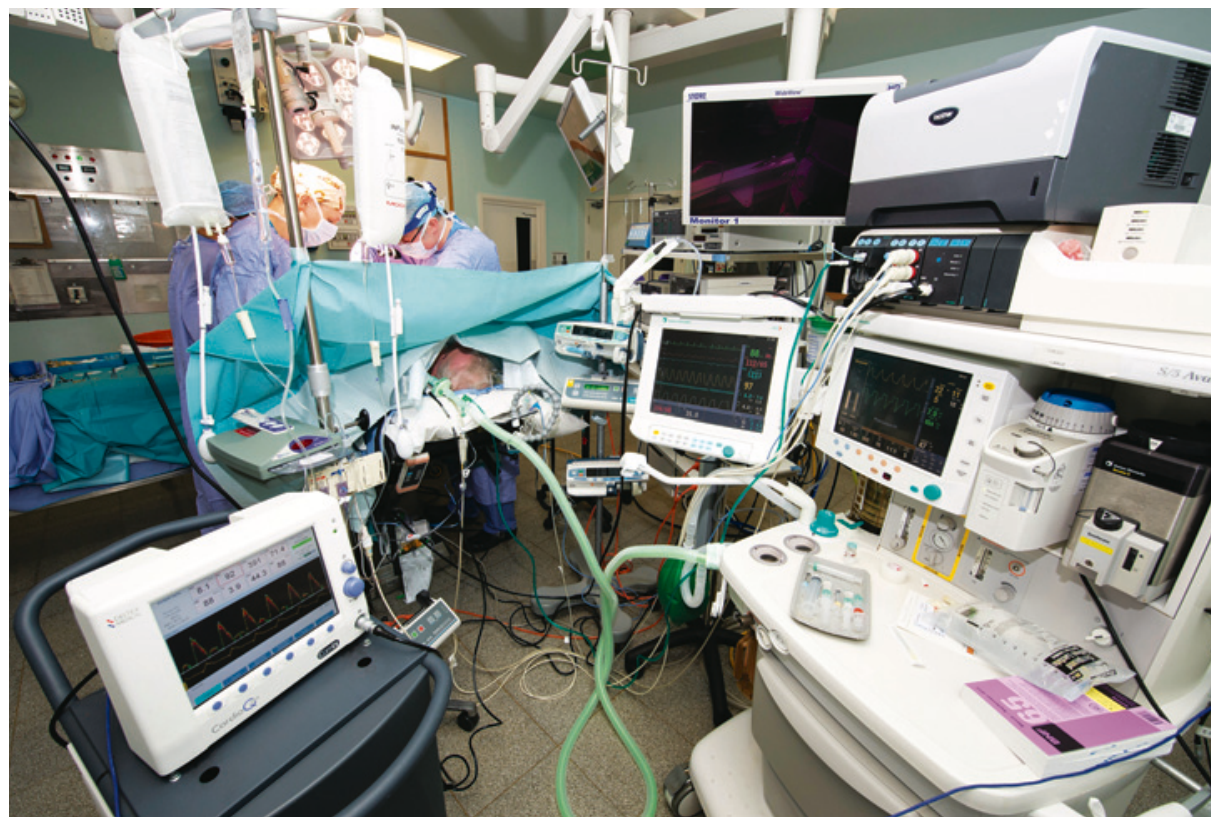

Illustrasjonsfoto: Science Photo Library

I en registerstudie med data fra 67 land fordelt på alle verdensdeler er femårsoverlevelsen for ulike kreftsykdommer estimert for perioden 1995-2009 (1). Tallene er justert for bakgrunnsdødeligheten i hvert land. Studien er basert på individuelle data for 25,7 millioner voksne pasienter og 75000 barn.

For pasienter med tykktarms- og endetarmskreft steg femårsoverlevelsen til minst $60 \%$ i over 22 land i løpet av studieperioden. For brystkreft steg den til $85 \%$ eller mer i 17 land. Pasienter med lever- eller lungekreft hadde fortsatt dårlig prognose ved slutten av studieperioden; femårsoverlevelsen var under $20 \%$ i alle studielandene.

Femårsoverlevelsen ved prostatakreft varierte fra mindre enn $60 \%$ i Bulgaria og Thailand til $95 \%$ eller mer i Brasil, Puerto Rico og USA. I flere land i Sør-Amerika, Asia og Europa hadde overlevelsen ved prostatakreft økt med 10-20\% i løpet av studie- perioden. Japan og Sør-Korea hadde klart best overlevelse blant pasienter med magekreft, mens de samme to landene var blant dem med lavest overlevelse blant voksne med leukemi. Blant barn med akutt lymfatisk leukemi var overlevelsen under $60 \%$ i mange land, men $90 \%$ eller mer i Canada og fire europeiske land, blant andre Norge.

Forskerne konkluderer med at de store forskjellene i femårsoverlevelse trolig skyldes ulik tilgang på optimal behandling og tidlig diagnostikk.

\section{Matilde Risopatron Berg}

Sykehuset Innlandet, Elverum

\section{Litteratur}

1. Allemani C, Weir HK, Carreira H et al. Global surveillance of cancer survival 1995-2009: analysis of individual data for 25676887 patients from 279 population-based registries in 67 countries (CONCORD-2). Lancet 2014; e-publisert 26.11.2014 